\title{
Mechanisms of HCV-induced liver cancer: What did we learn from in vitro and animal studies?
}

\author{
Ivan Rusyn ${ }^{1}$ and Stanley M. Lemon ${ }^{2}$ \\ ${ }^{1}$ Department of Environmental Sciences \& Engineering, University of North Carolina, Chapel Hill, \\ NC 27599, USA \\ ${ }^{2}$ Division of Infectious Diseases, Department of Medicine, University of North Carolina, Chapel \\ Hill, NC 27599, USA
}

\begin{abstract}
Hepatitis $\mathrm{C}$ virus $(\mathrm{HCV})$ is a cause of liver diseases that range from steatohepatitis, to fibrosis, cirrhosis, and hepatocellular carcinoma (HCC). The challenge of understanding the pathogenesis of HCV-associated liver cancer is difficult as most standard animal models used in biomedical research are not permissive to $\mathrm{HCV}$ infection. Herein, we provide an overview of a number of creative in vivo, mostly in the mouse, and in vitro models that have been developed to advance our understanding of the molecular and cellular effects of $\mathrm{HCV}$ on the liver, specifically with their relevance to $\mathrm{HCC}$.
\end{abstract}

\section{Introduction}

A recent re-analysis of the worldwide global burden of cancer [1] places liver as the $5^{\text {th }}$ most prevalent target organ in terms of the estimated new cases in man, and $7^{\text {th }}$ in women. Most importantly, liver cancer is one of the most deadly cancers, as it is the $2^{\text {nd }}$ leading cause of cancer death in man and $6^{\text {th }}$ in women worldwide. An estimated 748,000 new liver cancer cases and 696,000 cancer deaths occurred worldwide in 2008 with the highest liver cancer rates are reported in East and South-East Asia, and in Middle and Western Africa. Among primary liver cancers, hepatocellular carcinoma (HCC) represents the major subtype, accounting for $70 \%$ to $85 \%$ of the total liver cancer burden worldwide.

Among many potential etiological factors that have been causally linked to human cancers, including HCC, infectious agents represent an important sub-group of agents that have been classified as "carcinogenic to humans" by the International Agency for Research on Cancer Monographs Program [2]. Liver is a major cancer site associated with four Group 1 infectious agents: hepatitis $\mathrm{B}$ and $\mathrm{C}$ viruses, $O$. viverrini and $C$. sinensis. With regards to hepatitis $\mathrm{C}$ virus (HCV), the relative risk estimate for developing liver cancer in patients with serologically-confirmed HCV infection is estimated to be 17, as compared to 2.5 for HCV-associated non-Hodgkin lymphomas [3]. Importantly, the age-adjusted incidence of

(C) 2013 Elsevier Ireland Ltd. All rights reserved.

Corresponding author: Ivan Rusyn, M.D., Ph.D. Department of Environmental Sciences \& Engineering University of North Carolina at Chapel Hill Chapel Hill, NC 27599 Tel: 919-843-2596 iir@unc.edu.

Publisher's Disclaimer: This is a PDF file of an unedited manuscript that has been accepted for publication. As a service to our customers we are providing this early version of the manuscript. The manuscript will undergo copyediting, typesetting, and review of the resulting proof before it is published in its final citable form. Please note that during the production process errors may be discovered which could affect the content, and all legal disclaimers that apply to the journal pertain.

Conflict of Interest Statement

The authors have nothing to disclose. 
HCC is increasing in many countries, including the United States [4], and has been widely attributed to the spread of $\mathrm{HCV}$ infection in many industrialized countries [5].

About 2\%-3\% of the world's population is living with HCV infection, with country-specific prevalence rates ranging from $<1 \%$ to over $10 \%$ [6]. Each year, it is estimated that over 350,000 people die worldwide of HCV-related diseases, predominantly liver cirrhosis and liver cancer [6]. In the United States alone, HCV and associated diseases carry a very high economic burden and it was estimated in 2012 that there are over 50 new drugs in development to treat hepatitis $\mathrm{C}[7 ; 8]$. Given the societal, economic and other pressures, the field of HCV studies is very vibrant and spans the spectrum of investigations in infectious disease and virology from mechanistic and clinical research, to drug development and epidemiology. However, relatively few studies have focused on the mechanisms underlying the association of liver cancer with HCV, and it is still largely unresolved whether the virus is directly carcinogenic (e.g. causes mutations, genomic instability, or transformation of liver cells), or whether other pathological conditions in the liver (steatosis, inflammation, oxidative stress, and fibrogenesis) that are associated with the chronic viral infection are to blame [5].

Since the discovery of HCV in 1989 [9], our knowledge has expanded exponentially and a plethora of model systems is being utilized by researchers who are interested in HCV itself, or the diseases that HCV has been associated with. These include human subjects, nonhuman primates, genetically engineered mice, as well as both human- and animal-derived cells. The types of research questions that are being investigated using one or more of these model systems include: (i) the mechanisms of infection, viral life cycle and persistence; (ii) types, pathogenesis and mechanisms of $\mathrm{HCV}$-associated liver diseases, including $\mathrm{HCC}$; (iii) the role of co-morbidity and environmental co-exposure factors; (iv) pharmacotherapy options and treatment strategies; and (v) individual susceptibility factors. While there are a number of animal models for the study of HCV infection and related liver diseases (see [10] for a recent comprehensive review), few models have been applied to study the etiology and mechanisms of liver cancer.

\section{Mechanisms of HCV-associated liver carcinogenesis}

Evidence exists to suggest that $\mathrm{HCV}$ may be both directly and indirectly involved in the development and progression of HCC [5]. The evidence for the direct carcinogenic action of $\mathrm{HCV}$ is less prominent than that for other carcinogenic viruses (e.g. papillomaviruses, herpesviruses, Epstein-Barr virus) which integrate into cellular DNA and/or impair normal controls of proliferation and cell death. HCV is a positive-strand RNA virus that replicates outside of the nucleus and does not have any potential to integrate its genetic information into the host cell's genome. HCV, however, has been found to be able to hijack a number of normal molecular pathways that control cell cycle. Most attention has been devoted to the interaction of various HCV non-structural proteins with cellular proteins that control proliferation. For example NS5B has been shown to be bound in the cytoplasm to the retinoblastoma $(\mathrm{Rb})$ protein [11], the mechanism that is considered to be key in overcoming infection-induced blocks to cell proliferation [12]. HCV proteins (core, NS3 and NS5A) have also been suggested to disrupt the function of the tumor suppressor p53, which may be a synergistic effect to the loss of $\mathrm{Rb}$, but this interaction is not well understood (reviewed in [13]). In addition, [14] revealed that the viral protein NS4B activates the expression of several members of the PKC superfamily, stimulates the ERK/JNK signaling cascades, and represses SOCS3 expression, resulting in the activation of STAT3 by enhancing its phosphorylation. Activated STAT3 then stimulates MMP-2 and Bcl-2 expression, thereby resulting in deregulation of cell transformation and apoptosis. 
These and other associated downstream events, such as DNA damage and mutations resulting from inefficient cell cycle/apoptosis control, could lead to oncogenic transformation of the affected cells which ultimately may develop into tumors. While similar mechanisms may be part of indirect events leading to HCC (see below), the fact that therapeutically-induced sustained antiviral response in patients with HCV leads to severalfold reduction in the risk of HCC $[15 ; 16]$ is indicative of the prominent role that the virus plays in liver carcinogenesis. An over-arching issue with all of these cell culture studies, however, is that the expression levels of viral proteins are often much higher than that which occurs in the liver of infected persons. Studies in which individual viral proteins are ectopically expressed must also be viewed with caution, as the trafficking and cellular localization of these proteins may be quite different than in the infected hepatocyte.

The indirect mechanisms of carcinogenesis in the HCV-infected liver are thought to result from the loss of virus-bearing hepatocytes which may lead to the increased rates of proliferation. In addition, chronic inflammation and oxidative stress, coupled with increased proliferation, may result in accumulation of mutations and oncogenic transformation of hepatocytes (reviewed in [13]). The indirect mechanisms of carcinogenesis also seem likely as a relatively small percentage of hepatocytes are $\mathrm{HCV}$-infected in chronic carriers of the virus $[17 ; 18]$.

\section{Human genome-wide association studies (GWAS)}

Current human research in $\mathrm{HCV}$ field is primarily focused on understanding liver disease susceptibility and progression and development of new treatments and patient management strategies. There are major differences in how people respond to HCV infection and its treatment. In addition to the virus serotype-specific reasons, host-specific factors play a clear role in whether $\mathrm{HCV}$ will lead to chronic infection, as about $30 \%$ of persons who acquire $\mathrm{HCV}$ infection resolve viremia, leaving only the antibody response as a marker of prior exposure [19]. In addition, approximately $50 \%$ of the infected subjects do not respond to interferon-based therapies $[20 ; 21]$. At least 5 recent independent candidate-gene and genome-wide studies provide overwhelming evidence for the role of single nucleotide polymorphisms in and near the interleukin $(I L) 28 B$ gene in the pathogenesis of HCV infection (reviewed in [19]); however, few mechanistic clues exist to answer why IL-28B is associated with spontaneous and treatment-associated resolution of HCV infection. A number of other innate immunity genes have been also implicated, as the persons possessing particular human leukocyte antigen types are more likely to recover from HCV [22] and polymorphisms in genes encoding cytokines and other immunologic mediators also seem to explain some HCV recovery [23; 24; 25].

In the GWAS of HCV-related HCC [26] the $5^{\prime}$ flanking region of MICA, the MHC class I polypeptide-related sequence A gene on chromosome $6 \mathrm{p} 21.33$, was identified as susceptibility locus and confirmed in an independent cohort. Albeit the locus conferred a relatively small excess risk (odds ratio $=1.39$ ), the finding is biologically plausible as the level of soluble MICA protein, supposedly possessing anti-tumor activity through NK cells and CD8-positive T-cells, was lower in individuals harboring the risk allele. Interestingly, the authors found that the association of the risk allele was observed in the comparison between $\mathrm{CHC}$ and $\mathrm{HCC}$ patients, but not in the comparison between $\mathrm{CHC}$ patients and $\mathrm{HCV}$-negative controls, suggesting that the genetic variants are associated with progression from $\mathrm{CHC}$ to $\mathrm{HCC}$ rather than with the susceptibility to $\mathrm{HCV}$ infection. While potentially interesting, it was suggested that the risk allele in the MICA gene is actually responsible for increased progression of liver cirrhosis, which eventually contributes to development of HCC, because the study by Kumar et al. [26] did not use HCV-related cirrhosis without HCC as the controls [27]. A second GWAS of HCV-related HCC [28] was also conducted 
in Japan and identified a different gene, DEPDC5 (DEP domain containing 5) on chromosome 22, as associated with HCC risk and confirmed the association using an independent case-control population. Even though this study was slightly smaller in its patient cohort size, the odds ratio for the top locus was also modest at 1.75. Questions remain whether the susceptibility loci within MICA and DEPDC5 are associated with HCVrelated HCC in other ethnic groups, as both published studies were conducted in Japanese cohorts. A small-scale study of recurrence-free survival in Japanese HCV-infected subjects who underwent curative liver resection showed that polymorphisms in MICA or DEPDC5 do not correlate with HCC recurrence [29]. The authors did find that subjects with DEPDC5 minor allele have high susceptibility for HCC development, even if the fibrosis stage was low. Thus, additional studies on other populations, with stratification based on viral subgenotypes and degree of cirrhosis should provide more comprehensive information on the genetic etiology and heterogeneity of HCV-related HCC.

\section{Non-human primates}

Chimpanzees are the most relevant animal model for studies of HCV infection and related immune and other effects [30]. They are considered a "complete" model with replication, infection and virus production steps of the viral cycle. While the viremia levels are generally high and the human-like host response comprises both innate and adaptive immunity, the pathogenicity of $\mathrm{HCV}$ is relatively low in chimpanzees, making them a poor model for chronic liver disease and HCV-associated HCC [10]. Only a few HCV-related liver cancers have been reported in chimpanzees [31]. Moreover, virtually all use of chimpanzees in biomedical research is being suspended starting in 2013, following a report by the Institute of Medicine and a recommendation by a National Institutes of Health advisory panel. While a possible exception is considered for the development of $\mathrm{HCV}$ vaccines, this model system is increasingly difficult to access, and other non-human primates (e.g. the cynomolgus, green and Japanese monkeys, the tamarins and baboons) are non-permissive species for HCV infection [32].

\section{Mouse models}

The restricted host range of HCV has hampered the development of a suitable small animal model of HCV infection; however, a number of research strategies have been proposed to take advantage of the genetic engineering tools available in the mouse [10]. Of many mouse models that have been developed in the past decade, only HCV transgenic mouse strains have been employed in chronic studies designed to detect liver cancer as an endpoint.

\subsection{Chimeric mouse models}

A number of human liver chimeric mice were developed and are used as a model for $\mathrm{HCV}$ infection and treatment [33]. The original strategy was to use T- and B-cell deficient mice (termed SCID for severe combined immunodeficiency) that would tolerate human hepatocyte (or hepatic progenitor cell) grafts into the liver [34]. This model is known as the uPA model as it required, in addition to SCID phenotype, a plasminogen activator transgene (Alb-uPA) which resulted in a loss of murine hepatocytes. Homozygosity of Alb-uPA was associated with significantly higher levels of human hepatocyte engraftment in SCID mice [34]. These mice could be infected with human HCV viruses (via serum) of various genotypes and developed prolonged HCV infections with high viral titers after inoculation. $\mathrm{HCV}$ viral proteins were shown to be localized to human hepatocyte nodules, and infection was transferrable through three generations of mice confirming both synthesis and release of infectious viral particles. While this model, in many ways, was revolutionary, its limitations included excessive mortality, low breeding efficiency (since partially resolved by changing the genetic background), transgene reversion, and challenges of colony management due to 
frail immune state of the mice. While these mice can sustain long-term infection and are replicating the virus in a way similar to that of the human and chimpanzee liver [35], the immunodeficiency of this model system prevents studies of adaptive immune response to $\mathrm{HCV}$ infection. Importantly, there is no disease in these animals.

Another mouse model was developed to further increase the amount of grafting of human cells into mouse liver. The so-called FRG model $[36 ; 37]$ is mice lacking fumaryl acetoacetate hydrolase, recombination activating gene 2 , and the $\gamma$-chain of the receptor for IL-2. Up to $95 \%$ of human hepatocyte chimerism can be achieved in these animals, human $\mathrm{HCV}$ is effectively propagated, and the HCV-infected mice are responsive to antiviral treatment [36]. While productive HCV infection could be seen in these mice, similar to uPa mice, the lack of a functioning human immune system also precludes studies on immunopathogenesis which plays a central role in progressive disease in chronically infected individuals.

The most recent advancement in the chimeric mice for HCV research comes from the development of the mouse with human immune system and liver cells, a model with great promise to improve our understanding of HCV pathogenesis and treatment $[38 ; 39]$. To induce murine liver cell death, a fusion protein of the FK506 binding protein (FKBP) and caspase 8 under control of the albumin promoter (AFC8) was expressed in Balb/C Rag2/ Cnull mice. Next, human CD34+ human hematopoietic stem cells and hepatocyte progenitors were co-transplanted which resulted in efficient engraftment of human leukocytes and hepatocytes. These mice not only supported HCV infection in the liver and generated a human immune T-cell response against HCV, but also developed pronounced human-like molecular and histopathological signatures of liver hepatitis and fibrosis. While the initial experiments showed relatively low levels of $(\sim 15 \%)$ human hepatocyte engraftment and (possibly related) an absence of detectable HCV viremia, further improvements to this model are underway ( $\mathrm{Su}, \mathrm{L} .$, personal communication).

\subsection{Transgenic mouse models}

Studies in transgenic mouse models, in which various HCV proteins are stably expressed, indicate that HCV protein expression can be directly pathogenic and oncogenic [40; 41]. Although these model animals have a functional immune response which enables immunogenicity studies, the transgene is typically sensed as 'self' and does not engender an immune response. The transgenic animals also generally lack regulatory segments of the $\mathrm{HCV}$ genome and thus do not support replication of virus, even if all the viral proteins are expressed.

Several mouse models expressing HCV structural proteins (core, E1, E2 and p7) or nonstructural proteins (NS2, NS3, NS4A, NS4B, NS5A and NS5B), individually or in various combinations, are available $[42 ; 43]$. In these mice, proteins are constitutively expressed in all liver parenchymal cells owing to the control by liver-specific promoters. Most of the HCV transgenic mouse strains do not exhibit overt liver disease, especially in the first 12 months of life, despite high expression levels of HCV proteins. The earliest pathological liver phenotype that has been reported appears to be moderate to severe steatosis which develops between 3 and 10 months of age $[40 ; 41 ; 44]$, and is a common feature in humans with chronic $\mathrm{HCV}$ infection. Evidence for a spontaneous increase in oxidative stress in ageing HCV transgenic mice is limited [45], and is not accompanied by either inflammation or necrosis [46]. While hepatic tumors have been observed in some of these models $[40 ; 41 ; 47 ; 48 ; 49]$ the incidence varies widely. Liver tumors develop only in the mice of advanced (>13 months) age and largely without much adverse liver pathology, except for steatosis. A number of studies have used HCV transgenic mouse models for studies of co-carcinogenesis or co-morbidity (see below). 
A model of transient transfection with HCV proteins-containing plasmids has been also proposed [50; 51]. This model exploits the technique of hydrodynamic tail vein injection of naked plasmid DNA, a simple and effective in vivo gene delivery method into hepatocytes [52]. Transient hepatic transgene expression of the HCV nonstructural 3/4A protein was demonstrated by Ahlen et al [50] and it was estimated that 10-30\% of liver cells expressed the transgene as early as $24 \mathrm{hrs}$ post-infection. The advantages of this model are its flexibility with regards to the researcher's ability to transfect various parts of the HCV genome and the fact that not every cell is transfected, mimicking the human condition. The transient (i.e. short-term) nature of the transfection, however, precludes the use of this model in chronic and carcinogenesis studies.

\section{In vitro models}

\subsection{Primary human hepatocytes}

Among many in vitro models that have been used in $\mathrm{HCV}$ research, adult primary human hepatocytes are considered to be the most human-relevant cell-based liver model [53]. It has been demonstrated more than a decade ago that human serum-derived HCV may infect these cells in culture [54]. Primary adult human hepatocytes are permissive to viral genome replication, although the level of replication is typically very restricted in magnitude [55; 56]. Primary adult human hepatocytes are closest to the in vivo situation with respect to production of more authentic, lipid-associated HCV particles [57]. Importantly, this model system has been shown to induce an early innate antiviral response upon HCV infection [53] and be responsive to inhibition of HCV by interferon [58; 59]. In fact, the interferon response and innate immune response, even though desired features of this model, limit the spread of HCV infection [60; 61]. These cells are of limited access, difficult to handle, and support HCV replication only inefficiently [60], which makes them not widely used. Despite these limitations, potential relevance of this model to studies of $\mathrm{HCV}$-induced liver disease is considerable.

A recent report by Bose et al [62] suggested that HCV virus may induce epithelialmesenchymal transition in primary human hepatocytes. This study showed that cell culture-grown $\mathrm{HCV}$ leads to a transformation of primary hepatocyte cultures into fibroblastlike cells, which may explain the origins of the fibrotic response in human HCV-infected patients. The same group has shown previously that HCV infection of primary human hepatocytes may result in immortalization [63]. While intriguing, these findings need independent confirmation and a better understanding of the hepatocyte transition states from liver-like morphology to fibroblast or immortalized phenotype.

\subsection{Liver-derived cells}

One of the most widely used in vitro models for studies of $\mathrm{HCV}$ is the Huh7 cell line and its closely related variants. Very efficient replication of HCV can be achieved in these cells, possibly because of a high basal expression level of the liver-specific microRNA, miR-122. The binding of miR-122 to its target sequences in the HCV genome does not inhibit the function of the viral RNA but instead positively regulates its replication [64]. Fukuhara et al [65] showed that endogenous expression levels of miR-122 differ widely among hepatic and nonhepatic cells. In fact, it was observed that miR-122 expression was more than 2 orders of magnitude higher in Huh7 cells than that in HepG2 or Hep3B cells. Expression in non-liver derived cells (NCI-H-2030, SK-OV3, SW620, RERF-LC-AI, Caki-2, MC-IXC, 293T, Hec1B, 769-P, A-427, SW780, and SK-PN-DW) was even lower. Expression of miR-122 in HepG2 cells permitted efficient HCV RNA replication and infectious virion production. When a missing HCV receptor is also expressed, these cells support viral entry and the entire HCV life cycle [66]. Although Huh7 cells represent somewhat of a gold standard for 
permissiveness for $\mathrm{HCV}$ replication, they express a mutant $\mathrm{p} 53$ gene that is transcriptionally inactive and are thus not suitable for many studies related to $\mathrm{HCV}$-associated carcinogenesis.

Several studies have suggested that Hep3B cells can also support levels of HCV replication and virus particle production, similar to that found in Huh7-derived cells, with no selection or adaptation [67]. In addition, interferon-stimulated gene expression is significantly and differentially up-regulated in Hep3B cells following viral infection [68]. However, others have reported that while the early events in HCV infection are efficient in Hep3B cells, later steps of the viral life cycle such as steady-state replication, de novo virus production and/or spread are impaired compared to Huh7 cell cultures [68]. This diminished response was attributed, at least in part, to $\mathrm{HCV}$-induced innate signaling, similar to that in primary human hepatocytes.

Huh7 and other traditional cell-based models are used in conjunction with cell-culture adapted viruses and thus may not completely mimic the events that occur during a natural HCV infection in vivo [69]. Recently, HepaRG cells that are capable of differentiating into hepatocytes and biliary epithelial cells, were shown to be susceptible to in vitro infection with human serum-derived HCV and able to support long-term production of infectious lipoprotein-associated enveloped HCV particles [70]. This study also demonstrated the potential for HepaRG cells to be used as a surrogate infection system for the screening of viral entry inhibitors.

The in vitro models of $\mathrm{HCV}$ infection are also invaluable for translational clinical research. For example, while HCV infection treatment with interferon alfa (IFN-a) alters cellular response pathways of innate immunity to suppress $\mathrm{HCV}$ infection in many subjects, the response to such therapy is not uniform. Lau et al [71] modeled the relationship between chronic HCV replication, levels of IFN and the clinical observation of interferon-stimulated tolerance in hepatocytes. The authors demonstrate that when Huh7 cells were incubated with low levels IFN-a-2a, expression of interferon-stimulated genes was associated with an increase in level of HCV RNA indicating that constitutive exposure to IFN may induce some degree of interferon tolerance. This has also been described in the mouse liver [72].

\subsection{Extrahepatic cells}

miR-122 has been shown to enable replication of stable HCV RNA replicons in many nonliver cells, including human embryonic kidney epithelial (HEK-293) cells [73]. In other cell lines, such as wild-type murine fibroblasts that are restricted for HCV RNA replication, deletion of interferon regulatory factors and expression of liver-specific miR-122 is necessary to facilitate the synthesis of HCV replicons [74]. Still, while exogenous expression of miR-122 in non-hepatic cells facilitates efficient viral replication, production of infectious particles is lacking in such cells, possibly due to inefficient lipid metabolism. Indeed, $\mathrm{HCV}$ assembly is known to occur on the surface of lipid droplets, a process that is facilitated by the interaction of lipid droplet-associated protein TIP47 which binds to RNAloaded NS5A [75]. Liver-specific mechanisms for very-low density lipoprotein secretion also appear to be involved in HCV release from hepatocytes, and likely contribute to the hepato-tropism of the virus [76].

\subsection{Stem cell-derived liver-like cells}

The field of in vitro liver research has been recently enriched by the introduction of stem cell-derived liver-like cells. Recent studies show that both embryonic [77], and induced pluripotent [78] stem cells can be differentiated into hepatocytes that are phenotypically similar to human fetal liver. These models begin to be applied for studies of HCV. A human 
iPS-derived hepatocyte-like cell-based model [79] offers the possibility to study genetic defects that impact HCV infection. This study reported that induced human liver-like cells expressed known HCV host factors involved in HCV entry and supported the entire life cycle of genotype $2 \mathrm{a} \mathrm{HCV}$ reporter virus, and that incubation with antiviral drugs caused a significant decrease of viral production. Cell culture supernatants from this model were able to infect $\mathrm{HuH}-7.5$ cells, and $\mathrm{HCV}$ infection induced an antiviral inflammatory response similar to that induced in hepatocytes during chronic liver disease. Furthermore, secretion of TNF-a, and IL-28B/IL-29 was detected in cell culture supernatants. Therefore, as suggested by the authors, we can speculate that iPSCs generated from patients with a genetic background that impacts HCV infection could serve as a model for studying the influence of innate immunity on such infection, which could enhance our current understanding of interferon-based therapy.

\section{Use of mouse model systems to understand factors that facilitate cancer development in HCV-infected liver}

Spontaneous development of liver tumors have been observed only in a couple of HCV transgenic mouse strains, usually between 13 and 24 months of age [40; 41; 42]. Most of the HCV transgenic mouse models exhibit a limited overt liver phenotype, even late in life [42], yet are susceptible to a number of additional hepatotoxic challenges such as iron overload [80], carbon tetrachloride [81], alcohol [49], acetaminophen [82], or aflatoxin B1 [83].

Studies in HCV transgenic mice have demonstrated that expression of various HCV proteins may enhance susceptibility to other carcinogens. With regards to studies of comorbidity, iron overload [80], hepatitis B virus X protein [84], or intestinal colonization with $H$. hepaticus [85] have been shown to promote liver cancer in HCV-transgenic mice. With regards to studies of dietary factors, alcohol [49] and aflatoxin B1 [83] promoted the development of HCC in HCV transgenic mouse strains that normally do not develop cancer. These studies not only establish a model for studies of the mechanisms of co-carcinogenesis of $\mathrm{HCV}$ and other factors, but it also indicates a crucial role for direct viral protein effects in the synergy between these factors. Furthermore, these findings are particularly interesting because both alcohol ingestion and exposure to aflatoxin $\mathrm{B} 1$ are known to increase the risk of HCC in patients with chronic hepatitis C.

\section{Acknowledgments}

The authors were supported, in part, by grants from the National Institutes of Health: P42-ES005948, R01ES015241, R01-CA164029 and R01-AI095690.

\section{References}

1. Jemal A, Bray F, Center MM, Ferlay J, Ward E, Forman D. Global cancer statistics. CA Cancer J Clin. 2011; 61:69-90. [PubMed: 21296855]

2. Bouvard V, Baan R, Straif K, Grosse Y, Secretan B, El Ghissassi F, Benbrahim-Tallaa L, Guha N, Freeman C, Galichet L, Cogliano V, W.H.O. International Agency for Research on Cancer Monographs Working Group. A review of human carcinogens--Part B: biological agents. Lancet Oncol. 2009; 10:321-322. [PubMed: 19350698]

3. de Martel C, Ferlay J, Franceschi S, Vignat J, Bray F, Forman D, Plummer M. Global burden of cancers attributable to infections in 2008: a review and synthetic analysis. Lancet Oncol. 2012; 13:607-615. [PubMed: 22575588]

4. El-Serag HB. Hepatocellular carcinoma. N Engl J Med. 2011; 365:1118-1127. [PubMed: 21992124] 
5. Lemon SM, McGivern DR. Is hepatitis C virus carcinogenic? Gastroenterology. 2012; 142:12741278. [PubMed: 22537433]

6. Averhoff FM, Glass N, Holtzman D. Global burden of hepatitis C: considerations for healthcare providers in the United States. Clin Infect Dis. 2012; 55(Suppl 1):S10-15. [PubMed: 22715208]

7. El Khoury AC, Klimack WK, Wallace C, Razavi H. Economic burden of hepatitis C-associated diseases in the United States. J Viral Hepat. 2012; 19:153-160. [PubMed: 22329369]

8. Welsch C, Jesudian A, Zeuzem S, Jacobson I. New direct-acting antiviral agents for the treatment of hepatitis C virus infection and perspectives. Gut. 2012; 61(Suppl 1):i36-46. [PubMed: 22504918]

9. Choo QL, Kuo G, Weiner AJ, Overby LR, Bradley DW, Houghton M. Isolation of a cDNA clone derived from a blood-borne non-A, non-B viral hepatitis genome. Science. 1989; 244:359-362. [PubMed: 2523562]

10. Bukh J. Animal models for the study of hepatitis $\mathrm{C}$ virus infection and related liver disease. Gastroenterology. 2012; 142:1279-1287. e1273. [PubMed: 22537434]

11. Munakata T, Nakamura M, Liang Y, Li K, Lemon SM. Down-regulation of the retinoblastoma tumor suppressor by the hepatitis C virus NS5B RNA-dependent RNA polymerase. Proc Natl Acad Sci U S A. 2005; 102:18159-18164. [PubMed: 16332962]

12. Walters KA, Syder AJ, Lederer SL, Diamond DL, Paeper B, Rice CM, Katze MG. Genomic analysis reveals a potential role for cell cycle perturbation in $\mathrm{HCV}$-mediated apoptosis of cultured hepatocytes. PLoS Pathog. 2009; 5:e1000269. [PubMed: 19148281]

13. McGivern DR, Lemon SM. Virus-specific mechanisms of carcinogenesis in hepatitis $C$ virus associated liver cancer. Oncogene. 2011; 30:1969-1983. [PubMed: 21258404]

14. Li Y, Zhang Q, Liu Y, Luo Z, Kang L, Qu J, Liu W, Xia X, Liu Y, Wu K, Wu J. Hepatitis C virus activates Bcl-2 and MMP-2 expression through multiple cellular signaling pathways. J Virol. 2012; 86:12531-12543. [PubMed: 22951829]

15. Singal AK, Singh A, Jaganmohan S, Guturu P, Mummadi R, Kuo YF, Sood GK. Antiviral therapy reduces risk of hepatocellular carcinoma in patients with hepatitis $\mathrm{C}$ virus-related cirrhosis. Clin Gastroenterol Hepatol. 2010; 8:192-199. [PubMed: 19879972]

16. Bruno S, Stroffolini T, Colombo M, Bollani S, Benvegnu L, Mazzella G, Ascione A, Santantonio T, Piccinino F, Andreone P, Mangia A, Gaeta GB, Persico M, Fagiuoli S, Almasio PL, D. Italian Association of the Study of the Liver. Sustained virological response to interferon-alpha is associated with improved outcome in HCV-related cirrhosis: a retrospective study. Hepatology. 2007; 45:579-587. [PubMed: 17326216]

17. Bigger CB, Guerra B, Brasky KM, Hubbard G, Beard MR, Luxon BA, Lemon SM, Lanford RE. Intrahepatic gene expression during chronic hepatitis $\mathrm{C}$ virus infection in chimpanzees. J Virol. 2004; 78:13779-13792. [PubMed: 15564486]

18. Liang Y, Shilagard T, Xiao SY, Snyder N, Lau D, Cicalese L, Weiss H, Vargas G, Lemon SM. Visualizing hepatitis $\mathrm{C}$ virus infections in human liver by two-photon microscopy. Gastroenterology. 2009; 137:1448-1458. [PubMed: 19632233]

19. Thio CL, Thomas DL. Interleukin-28b: a key piece of the hepatitis C virus recovery puzzle. Gastroenterology. 2010; 138:1240-1243. [PubMed: 20184973]

20. Rauch A, Kutalik Z, Descombes P, Cai T, Di Iulio J, Mueller T, Bochud M, Battegay M, Bernasconi E, Borovicka J, Colombo S, Cerny A, Dufour JF, Furrer H, Gunthard HF, Heim M, Hirschel B, Malinverni R, Moradpour D, Mullhaupt B, Witteck A, Beckmann JS, Berg T, Bergmann S, Negro F, Telenti A, Bochud PY, Swiss Hepatitis CCS, Swiss HIVCS. Genetic variation in IL28B is associated with chronic hepatitis C and treatment failure: a genome-wide association study. Gastroenterology. 2010; 138:1338-1345. 1345, e1331-1337. [PubMed: 20060832]

21. Feld JJ, Hoofnagle JH. Mechanism of action of interferon and ribavirin in treatment of hepatitis C. Nature. 2005; 436:967-972. [PubMed: 16107837]

22. Thursz M, Yallop R, Goldin R, Trepo C, Thomas HC. Influence of MHC class II genotype on outcome of infection with hepatitis $\mathrm{C}$ virus. The HENCORE group. Hepatitis $\mathrm{C}$ European Network for Cooperative Research. Lancet. 1999; 354:2119-2124. [PubMed: 10609818] 
23. Thio CL, Goedert JJ, Mosbruger T, Vlahov D, Strathdee SA, O'Brien SJ, Astemborski J, Thomas DL. An analysis of tumor necrosis factor alpha gene polymorphisms and haplotypes with natural clearance of hepatitis C virus infection. Genes Immun. 2004; 5:294-300. [PubMed: 15071492]

24. An P, Thio CL, Kirk GD, Donfield S, Goedert JJ, Winkler CA. Regulatory polymorphisms in the interleukin-18 promoter are associated with hepatitis C virus clearance. J Infect Dis. 2008; 198:1159-1165. [PubMed: 18781864]

25. Huang Y, Yang H, Borg BB, Su X, Rhodes SL, Yang K, Tong X, Tang G, Howell CD, Rosen HR, Thio CL, Thomas DL, Alter HJ, Sapp RK, Liang TJ. A functional SNP of interferon-gamma gene is important for interferon-alpha-induced and spontaneous recovery from hepatitis $\mathrm{C}$ virus infection. Proc Natl Acad Sci U S A. 2007; 104:985-990. [PubMed: 17215375]

26. Kumar V, Kato N, Urabe Y, Takahashi A, Muroyama R, Hosono N, Otsuka M, Tateishi R, Omata M, Nakagawa H, Koike K, Kamatani N, Kubo M, Nakamura Y, Matsuda K. Genome-wide association study identifies a susceptibility locus for HCV-induced hepatocellular carcinoma. Nat Genet. 2011; 43:455-458. [PubMed: 21499248]

27. Hoshida Y, Fuchs BC, Tanabe KK. Genomic risk of hepatitis C-related hepatocellular carcinoma. J Hepatol. 2012; 56:729-730. [PubMed: 21963516]

28. Miki D, Ochi H, Hayes CN, Abe H, Yoshima T, Aikata H, Ikeda K, Kumada H, Toyota J, Morizono T, Tsunoda T, Kubo M, Nakamura Y, Kamatani N, Chayama K. Variation in the DEPDC5 locus is associated with progression to hepatocellular carcinoma in chronic hepatitis $\mathrm{C}$ virus carriers. Nat Genet. 2011; 43:797-800. [PubMed: 21725309]

29. Motomura T, Ono Y, Shirabe K, Fukuhara T, Konishi H, Mano Y, Toshima T, Yoshiya S, Muto J, Ikegami T, Yoshizumi T, Maehara Y. Neither MICA Nor DEPDC5 Genetic Polymorphisms Correlate with Hepatocellular Carcinoma Recurrence following Hepatectomy. HPB Surg. 2012; 2012:185496. [PubMed: 23132957]

30. Houghton M. Prospects for prophylactic and therapeutic vaccines against the hepatitis $C$ viruses. Immunol Rev. 2011; 239:99-108. [PubMed: 21198667]

31. Lanford, RE.; Lemon, SM.; Walker, C. The chimpanzee model of hepatitis C infections and small animal surrogates. In: He, Y.; Tan, T., editors. Hepatitis C Antiviral Drug Discovery \& Development. Horizons Scientific Press; Norwich, CT: 2011. p. 99-132.

32. Meuleman P, Leroux-Roels G. The human liver-uPA-SCID mouse: a model for the evaluation of antiviral compounds against HBV and HCV. Antiviral Res. 2008; 80:231-238. [PubMed: 18706933]

33. Akkina R. New generation humanized mice for virus research: comparative aspects and future prospects. Virology. 2013; 435:14-28. [PubMed: 23217612]

34. Mercer DF, Schiller DE, Elliott JF, Douglas DN, Hao C, Rinfret A, Addison WR, Fischer KP, Churchill TA, Lakey JR, Tyrrell DL, Kneteman NM. Hepatitis C virus replication in mice with chimeric human livers. Nat Med. 2001; 7:927-933. [PubMed: 11479625]

35. Bissig KD, Wieland SF, Tran P, Isogawa M, Le TT, Chisari FV, Verma IM. Human liver chimeric mice provide a model for hepatitis B and C virus infection and treatment. J Clin Invest. 2010; 120:924-930. [PubMed: 20179355]

36. Bissig KD, Le TT, Woods NB, Verma IM. Repopulation of adult and neonatal mice with human hepatocytes: a chimeric animal model. Proc Natl Acad Sci U S A. 2007; 104:20507-20511. [PubMed: 18077355]

37. Azuma H, Paulk N, Ranade A, Dorrell C, Al-Dhalimy M, Ellis E, Strom S, Kay MA, Finegold M, Grompe M. Robust expansion of human hepatocytes in Fah-/-/Rag2-/-/I12rg-/-mice. Nat Biotechnol. 2007; 25:903-910. [PubMed: 17664939]

38. Bility MT, Zhang L, Washburn ML, Curtis TA, Kovalev GI, Su L. Generation of a humanized mouse model with both human immune system and liver cells to model hepatitis $\mathrm{C}$ virus infection and liver immunopathogenesis. Nat Protoc. 2012; 7:1608-1617. [PubMed: 22899330]

39. Washburn ML, Bility MT, Zhang L, Kovalev GI, Buntzman A, Frelinger JA, Barry W, Ploss A, Rice CM, Su L. A humanized mouse model to study hepatitis $\mathrm{C}$ virus infection, immune response, and liver disease. Gastroenterology. 2011; 140:1334-1344. [PubMed: 21237170] 
40. Moriya K, Fujie H, Shintani Y, Yotsuyanagi H, Tsutsumi T, Ishibashi K, Matsuura Y, Kimura S, Miyamura T, Koike K. The core protein of hepatitis $\mathrm{C}$ virus induces hepatocellular carcinoma in transgenic mice. Nat Med. 1998; 4:1065-1067. [PubMed: 9734402]

41. Lerat H, Honda M, Beard MR, Loesch K, Sun J, Yang Y, Okuda M, Gosert R, Xiao SY, Weinman $\mathrm{SA}$, Lemon SM. Steatosis and liver cancer in transgenic mice expressing the structural and nonstructural proteins of hepatitis C virus. Gastroenterology. 2002; 122:352-365. [PubMed: 11832450]

42. Koike K, Moriya K, Matsuura Y. Animal models for hepatitis C and related liver disease. Hepatol.Res. 2010; 40:69-82. [PubMed: 20156300]

43. Li Y, Tang ZY, Hou JX. Hepatocellular carcinoma: insight from animal models. Nat Rev Gastroenterol Hepatol. 2012; 9:32-43. [PubMed: 22025031]

44. Moriya K, Yotsuyanagi H, Shintani Y, Fujie H, Ishibashi K, Matsuura Y, Miyamura T, Koike K. Hepatitis C virus core protein induces hepatic steatosis in transgenic mice. J Gen Virol. 1997; 78(Pt 7):1527-1531. [PubMed: 9225025]

45. Korenaga M, Wang T, Li Y, Showalter LA, Chan T, Sun J, Weinman SA. Hepatitis C Virus Core Protein Inhibits Mitochondrial Electron Transport and Increases Reactive Oxygen Species (ROS) Production. J Biol.Chem. 2005; 280:37481-37488. [PubMed: 16150732]

46. Moriya K, Nakagawa K, Santa T, Shintani Y, Fujie H, Miyoshi H, Tsutsumi T, Miyazawa T, Ishibashi K, Horie T, Imai K, Todoroki T, Kimura S, Koike K. Oxidative stress in the absence of inflammation in a mouse model for hepatitis $\mathrm{C}$ virus-associated hepatocarcinogenesis. Cancer Res. 2001; 61:4365-4370. [PubMed: 11389061]

47. Liang TJ, Heller T. Pathogenesis of hepatitis C-associated hepatocellular carcinoma. Gastroenterology. 2004; 127:S62-S71. [PubMed: 15508105]

48. Naas T, Ghorbani M, Alvarez-Maya I, Lapner M, Kothary R, De Repentigny Y, Gomes S, Babiuk L, Giulivi A, Soare C, Azizi A, Diaz-Mitoma F. Characterization of liver histopathology in a transgenic mouse model expressing genotype 1a hepatitis $\mathrm{C}$ virus core and envelope proteins 1 and 2. J Gen Virol. 2005; 86:2185-2196. [PubMed: 16033966]

49. Machida K, Tsukamoto H, Mkrtchyan H, Duan L, Dynnyk A, Liu HM, Asahina K, Govindarajan S, Ray R, Ou JH, Seki E, Deshaies R, Miyake K, Lai MM. Toll-like receptor 4 mediates synergism between alcohol and HCV in hepatic oncogenesis involving stem cell marker Nanog. Proc.Natl.Acad Sci U.S.A. 2009; 106:1548-1553. [PubMed: 19171902]

50. Ahlen G, Nystrom J, Pult I, Frelin L, Hultgren C, Sallberg M. In vivo clearance of hepatitis C virus nonstructural 3/4A-expressing hepatocytes by DNA vaccine-primed cytotoxic T lymphocytes. J Infect Dis. 2005; 192:2112-2116. [PubMed: 16288375]

51. Ahlen G, Sallberg M, Frelin L. Methods for monitoring gene gun-induced HBV-and HCV-specific immune responses in mouse models. Methods Mol Biol. 2013; 940:239-267. [PubMed: 23104348]

52. Hodges BL, Scheule RK. Hydrodynamic delivery of DNA. Expert Opin Biol Ther. 2003; 3:911918. [PubMed: 12943450]

53. Pichard-Garcia L, Briolotti P, Larrey D, Sa-Cunha A, Suc B, Laporte S, Maurel P. Use of human hepatocytes to investigate HCV infection. Methods Mol Biol. 2010; 640:447-462. [PubMed: 20645067]

54. Fournier C, Sureau C, Coste J, Ducos J, Pageaux G, Larrey D, Domergue J, Maurel P. In vitro infection of adult normal human hepatocytes in primary culture by hepatitis $\mathrm{C}$ virus. J Gen Virol. 1998; 79(Pt 10):2367-2374. [PubMed: 9780041]

55. Buck M. Direct infection and replication of naturally occurring hepatitis $\mathrm{C}$ virus genotypes $1,2,3$ and 4 in normal human hepatocyte cultures. PLoS One. 2008; 3:e2660. [PubMed: 18628977]

56. Chong TW, Smith RL, Hughes MG, Camden J, Rudy CK, Evans HL, Sawyer RG, Pruett TL. Primary human hepatocytes in spheroid formation to study hepatitis C infection. J Surg Res. 2006; 130:52-57. [PubMed: 16154152]

57. Podevin P, Carpentier A, Pene V, Aoudjehane L, Carriere M, Zaidi S, Hernandez C, Calle V, Meritet JF, Scatton O, Dreux M, Cosset FL, Wakita T, Bartenschlager R, Demignot S, Conti F, Rosenberg AR, Calmus Y. Production of infectious hepatitis $\mathrm{C}$ virus in primary cultures of human adult hepatocytes. Gastroenterology. 2010; 139:1355-1364. [PubMed: 20600021] 
58. Molina S, Castet V, Fournier-Wirth C, Pichard-Garcia L, Avner R, Harats D, Roitelman J, Barbaras R, Graber P, Ghersa P, Smolarsky M, Funaro A, Malavasi F, Larrey D, Coste J, Fabre JM, Sa-Cunha A, Maurel P. The low-density lipoprotein receptor plays a role in the infection of primary human hepatocytes by hepatitis C virus. J Hepatol. 2007; 46:411-419. [PubMed: 17156886]

59. Castet V, Fournier C, Soulier A, Brillet R, Coste J, Larrey D, Dhumeaux D, Maurel P, Pawlotsky JM. Alpha interferon inhibits hepatitis $\mathrm{C}$ virus replication in primary human hepatocytes infected in vitro. J Virol. 2002; 76:8189-8199. [PubMed: 12134024]

60. Andrus L, Marukian S, Jones CT, Catanese MT, Sheahan TP, Schoggins JW, Barry WT, Dustin LB, Trehan K, Ploss A, Bhatia SN, Rice CM. Expression of paramyxovirus V proteins promotes replication and spread of hepatitis $\mathrm{C}$ virus in cultures of primary human fetal liver cells. Hepatology. 2011; 54:1901-1912. [PubMed: 22144107]

61. Rau SJ, Hildt E, Himmelsbach K, Thimme R, Wakita T, Blum HE, Fischer R. CD40 inhibits replication of hepatitis $\mathrm{C}$ virus in primary human hepatocytes by c-Jun $\mathrm{N}$ terminal kinase activation independent from the interferon pathway. Hepatology. 2013; 57:23-36. [PubMed: 22814930]

62. Bose SK, Meyer K, Di Bisceglie AM, Ray RB, Ray R. Hepatitis C virus induces epithelialmesenchymal transition in primary human hepatocytes. J Virol. 2012; 86:13621-13628. [PubMed: 23035229]

63. Ray RB, Meyer K, Ray R. Hepatitis C virus core protein promotes immortalization of primary human hepatocytes. Virology. 2000; 271:197-204. [PubMed: 10814584]

64. Jopling CL, Yi M, Lancaster AM, Lemon SM, Sarnow P. Modulation of hepatitis C virus RNA abundance by a liver-specific MicroRNA. Science. 2005; 309:1577-1581. [PubMed: 16141076]

65. Fukuhara T, Kambara H, Shiokawa M, Ono C, Katoh H, Morita E, Okuzaki D, Maehara Y, Koike $\mathrm{K}$, Matsuura Y. Expression of microRNA miR-122 facilitates an efficient replication in nonhepatic cells upon infection with hepatitis C virus. J Virol. 2012; 86:7918-7933. [PubMed: 22593164]

66. Narbus CM, Israelow B, Sourisseau M, Michta ML, Hopcraft SE, Zeiner GM, Evans MJ. HepG2 cells expressing microRNA miR-122 support the entire hepatitis C virus life cycle. J Virol. 2011; 85:12087-12092. [PubMed: 21917968]

67. Kambara H, Fukuhara T, Shiokawa M, Ono C, Ohara Y, Kamitani W, Matsuura Y. Establishment of a novel permissive cell line for the propagation of hepatitis $\mathrm{C}$ virus by expression of microRNA miR122. J Virol. 2012; 86:1382-1393. [PubMed: 22114337]

68. Bukong TN, Hou W, Kodys K, Szabo G. Ethanol facilitates hepatitis C virus replication via upregulation of GW182 and heat shock protein 90 in human hepatoma cells. Hepatology. 2013; 57:70-80. [PubMed: 22898980]

69. Si-Tayeb K, Duclos-Vallee JC, Petit MA. Hepatocyte-like cells differentiated from human induced pluripotent stem cells (iHLCs) are permissive to hepatitis C virus (HCV) infection: HCV study gets personal. J Hepatol. 2012; 57:689-691. [PubMed: 22565120]

70. Ndongo-Thiam N, Berthillon P, Errazuriz E, Bordes I, De Sequeira S, Trepo C, Petit MA. Longterm propagation of serum hepatitis $\mathrm{C}$ virus $(\mathrm{HCV})$ with production of enveloped $\mathrm{HCV}$ particles in human HepaRG hepatocytes. Hepatology. 2011; 54:406-417. [PubMed: 21520209]

71. Lau DT, Negash A, Chen J, Crochet N, Sinha M, Zhang Y, Guedj J, Holder S, Saito T, Lemon SM, Luxon BA, Perelson AS, Gale M Jr. Innate Immune Tolerance and the Role of Kupffer Cells in Differential Responses to Interferon Therapy Among Patients With HCV Genotype 1 Infection. Gastroenterology. 2012

72. Sarasin-Filipowicz M, Wang X, Yan M, Duong FH, Poli V, Hilton DJ, Zhang DE, Heim MH. Alpha interferon induces long-lasting refractoriness of JAK-STAT signaling in the mouse liver through induction of USP18/UBP43. Mol Cell Biol. 2009; 29:4841-4851. [PubMed: 19564419]

73. Chang J, Guo JT, Jiang D, Guo H, Taylor JM, Block TM. Liver-specific microRNA miR-122 enhances the replication of hepatitis C virus in nonhepatic cells. J Virol. 2008; 82:8215-8223. [PubMed: 18550664]

74. Lin LT, Noyce RS, Pham TN, Wilson JA, Sisson GR, Michalak TI, Mossman KL, Richardson CD. Replication of subgenomic hepatitis $\mathrm{C}$ virus replicons in mouse fibroblasts is facilitated by 
deletion of interferon regulatory factor 3 and expression of liver-specific microRNA 122. J Virol. 2010; 84:9170-9180. [PubMed: 20592082]

75. Ploen D, Hafirassou ML, Himmelsbach K, Sauter D, Biniossek ML, Weiss TS, Baumert TF, Schuster C, Hildt E. TIP47 plays a crucial role in the life cycle of hepatitis C virus. J Hepatol. 2013

76. Gastaminza P, Cheng G, Wieland S, Zhong J, Liao W, Chisari FV. Cellular determinants of hepatitis C virus assembly, maturation, degradation, and secretion. J Virol. 2008; 82:2120-2129. [PubMed: 18077707]

77. Funakoshi N, Duret C, Pascussi JM, Blanc P, Maurel P, Daujat-Chavanieu M, Gerbal-Chaloin S. Comparison of hepatic-like cell production from human embryonic stem cells and adult liver progenitor cells: CAR transduction activates a battery of detoxification genes. Stem Cell Rev. 2011; 7:518-531. [PubMed: 21210253]

78. Si-Tayeb K, Noto FK, Nagaoka M, Li J, Battle MA, Duris C, North PE, Dalton S, Duncan SA. Highly efficient generation of human hepatocyte-like cells from induced pluripotent stem cells. Hepatology. 2010; 51:297-305. [PubMed: 19998274]

79. Schwartz RE, Trehan K, Andrus L, Sheahan TP, Ploss A, Duncan SA, Rice CM, Bhatia SN. Modeling hepatitis $\mathrm{C}$ virus infection using human induced pluripotent stem cells. Proc Natl Acad Sci U S A. 2012; 109:2544-2548. [PubMed: 22308485]

80. Furutani T, Hino K, Okuda M, Gondo T, Nishina S, Kitase A, Korenaga M, Xiao SY, Weinman SA, Lemon SM, Sakaida I, Okita K. Hepatic iron overload induces hepatocellular carcinoma in transgenic mice expressing the hepatitis C virus polyprotein. Gastroenterology. 2006; 130:20872098. [PubMed: 16762631]

81. Chouteau P, Defer N, Florimond A, Calderaro J, Higgs M, Gaudin A, Merour E, Dhumeaux D, Lerat $\mathrm{H}$, Pawlotsky JM. Hepatitis $\mathrm{C}$ virus (HCV) protein expression enhances hepatic fibrosis in HCV transgenic mice exposed to a fibrogenic agent. J Hepatol. 2012; 57:499-507. [PubMed: 22613003]

82. Uehara T, Kosyk O, Jeannot E, Bradford BU, Tech K, Macdonald JM, Boorman GA, Chatterjee S, Mason RP, Melnyk SB, Tryndyak VP, Pogribny IP, Rusyn I. Acetaminophen-induced acute liver injury in HCV transgenic mice. Toxicol Appl Pharmacol. 2013; 266:224-232. [PubMed: 23200774]

83. Jeannot E, Boorman GA, Kosyk O, Bradford BU, Shymoniak S, Tumurbaatar B, Weinman SA, Melnyk SB, Tryndyak V, Pogribny IP, Rusyn I. Increased incidence of aflatoxin B1-induced liver tumors in hepatitis virus $\mathrm{C}$ transgenic mice. Int J Cancer. 2012; 130:1347-1356. [PubMed: 21500192]

84. Keasler VV, Lerat H, Madden CR, Finegold MJ, McGarvey MJ, Mohammed EM, Forbes SJ, Lemon SM, Hadsell DL, Grona SJ, Hollinger FB, Slagle BL. Increased liver pathology in hepatitis $\mathrm{C}$ virus transgenic mice expressing the hepatitis B virus X protein. Virology. 2006; 347:466-475. [PubMed: 16427673]

85. Fox JG, Feng Y, Theve EJ, Raczynski AR, Fiala JL, Doernte AL, Williams M, McFaline JL, Essigmann JM, Schauer DB, Tannenbaum SR, Dedon PC, Weinman SA, Lemon SM, Fry RC, Rogers AB. Gut microbes define liver cancer risk in mice exposed to chemical and viral transgenic hepatocarcinogens. Gut. 2010; 59:88-97. [PubMed: 19850960] 